The International Journal

ENTREPRENEURSHIP AND SUSTAINABILITY ISSUES

ISSN 2345-0282 (online) http://jssidoi.org/jesi/aims-and-scope-of-research/ 2015 Volume 3 Number 2 (December)

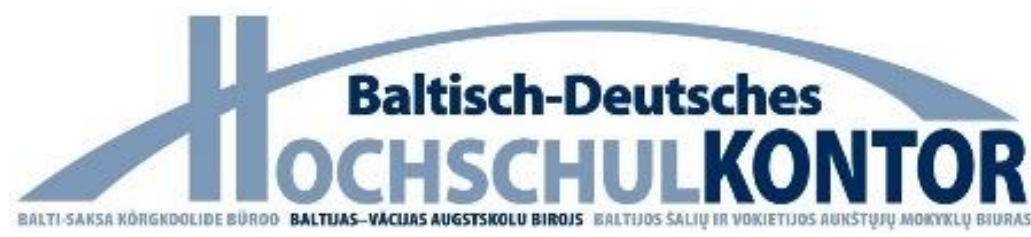

„The paper was published with support from the Baltic-German University Liaison Office from funds of the German Academic Exchange Service (DAAD)"

\title{
COOPERATION PROJECTS BETWEEN UNIVERSITY AND COMPANIES: PROCESS OF FORMATION AND OBJECTIVES OF THE STAKEHOLDERS
}

\author{
Eva Branten', Alari Purju² \\ 1,2 Tallinn University of Technology, Department of Logistics and Transport, Akadeemia tee 15A, Tallinn, Estonia \\ E-mails: ${ }^{1}$ alari.purju@ttu.ee; ${ }^{2}$ eva.branten@ttu.ee
}

Received 25 August 2015; accepted 18 October 2015

\begin{abstract}
This paper scrutinizes cooperation projects between universities and companies. The well-functioning links between universities and companies and knowledge transfer in supporting the economic growth are becoming increasingly more important. One link between universities and companies by means of which the knowledge transfer can take place is cooperation projects. The formation of the cooperation projects and objectives of the stakeholders as well as possibilities to clarify these objectives in order to promote and facilitate the cooperation projects are discussed in the paper. As an example, the concept and process of formation of cooperation projects of Innovation and Business Centre MEKTORY of Tallinn University of Technology are described.
\end{abstract}

Keywords: university-industry relations, cooperation projects, knowledge transfer, technology transfer office

Reference to this paper should be made as follows: Branten, E.; Purju, A. 2015. Cooperation projects between university and companies: process of formation and objectives of the stakeholders, Entrepreneurship and Sustainability Issues 3(2): 149-156 DOI: http://dx.doi.org/10.9770/jesi.2015.3.2(3)

JEL Classifications: $\mathrm{O} 32$ 


\section{Introduction}

This paper discusses the objectives and formation of cooperation projects between universities and companies. The knowledge exchange and research cooperation between the research and business sector are considered important for promoting technological change and economic growth. The cooperation projects between universities and companies are important in the paradigm of „Mode 2“. The paradigm of „Mode 2“ describes knowledge production which relies on interdisciplinary teams cooperating together for short periods to work on specific problems in the real world (Gibbons et al. 1994). The concept of the Triple Helix underlines the importance of the university-industry-government relations. According to the concept of Triple Helix the university can have the enhanced role in innovation in increasingly knowledge-based society (Etzkowitz et al. 2000).

The importance of knowledge transfer and cooperation between academic and business sector has been emphasized in Estonian Research and Development and Innovation Strategy 2014-2020 „Knowledge-based Estonia“" (Eesti teadus- ja arendustegevuse ning innovatsiooni strateegia 2014-2020).

Schartinger et al. (2002) analyze the patterns of knowledge interactions between academic and business sector in case of different fields of research and sectors of economic activity. They find that the intensity of knowledge interactions is not relevantly related to the research intensity of the sector. The analysis of sectoral patterns of knowledge interactions can give valuable input for the design of university-industry cooperation. Bekkers et al. (2008) analyze knowledge transfer channels between universities and companies in case of different economic sectors. According to Hsu et al. (2015) the possible mechanisms and activities by means of which knowledge can be transferred from university to industry include launching technology-oriented start-ups, and providing collaborative research, contract research, consulting services, technology licensing, graduate education, advanced training for enterprise staff, exchange of research staff, and other forms of formal or informal information transfer. Santoro and Chakrabarti (2002) discuss the differences in the knowledge transferred in industry-university interactions and find that larger more mechanistic companies are using these interactions more to build competencies in non-core technological areas whereas smaller high-tech companies are targeting problem solving in core technological areas. Santoro and Gopalakrishnan (2000) discuss the organizational factors affecting the process of knowledge transfer. O'Kane et al. (2015) discuss the questions of the formation of identity of Technology Transfer Offices in relations with the actors of the university.

The concept and process of formation of cooperation projects of Innovation and Business Centre MEKTORY of Tallinn University of Technology are also described as an example of cooperation projects between universities and companies in the article.

\section{The drivers of the university-industry partnerships and objectives of the stakeholders}

The study of Berbegal-Mirabent et al. (2015) clarifies the organizational and institutional aspects that act as drivers for the establishment of successful university-industry partnerships. Under scrutiny in the study are $\mathrm{R} \& \mathrm{D}$ contracts as a way of transferring academic knowledge to companies. The clarification of the factors determining the success of $R \& D$ contracts of universities is important since universities face constraints on resources and changes in their environment (Berbegal-Mirabent et al. 2015; Tvaronavičiené, Černevičiùtè 2015). Important factors include organizational capabilities, internal resources, and services that support research and knowledge transfer activities at universities whereas the model comprises two dimensions: Universities and Technology Transfer Offices. Universities provide knowledge, technology, and research expertise whereas Technology Transfer Offices facilitate and accelerate the relationship between business and academic sector (Berbegal-Mirabent et al. 2015). To estimate the statistical significance of different factors regression models are elaborated (Ibid.).

In order to facilitate cooperation between university and business sector, a clear view concerning the aims and motives of actors of university as well as business sector is needed. Ankrah et al. (2013) use qualitative approach (relying primarly on interviews) to investigate the university and industry actors' motives to engage in university-industry knowledge transfer. According to the study, university actors most frequently held as the benefits arising from cooperation the source of funding for research work; creation of business opportunities; exposure of the practical problems/ new ideas and/or state-of-the-art technology to the students and faculty, with positive effects on the curriculum; stimulation of technological advancement and/or research 
activities in certain key areas; training and employment opportunities for students; access to wider network/ networking possibilities. Industry actors most frequently held as the benefits arising from cooperation that the cooperation resulted in more cost-effective research than similar research in-house; improved innovative ability and capacity/ strengthened research base; exposure/ access to new knowledge and leading edge technologies; the opportunity to keep up to date with technological developments in universities/ university research capabilities; solution of specific technical problems or development of bespoke and tailored projects; opportunity to access a wider network of research expertise (Ankrah et al. 2013).

A wide overview of the studies concerning the motives, objectives and drawbacks from the point of view of the stakeholders of university-industry cooperation in knowledge transfer is presented in Ankrah et al. (2013). Ankrah et al. (2013) divide the benefits arising from the cooperation in the following groups: financial/economic benefits; organisational benefits; societal benefts. The drawbacks are grouped as follows: digression from the organisation's mission or objective; issues relating to quality; conflicts and risks (Ankrah et al. 2013).

An interesting question is the extent to which the motives, objectives and feared shortcomings are similar among different stakeholders. Ankrah et al. 2013 point out as the result of their study that ,the motives of university actors and industry actors using Oliver's theoretical framework are consistent at the determinant (i.e. summary) level but differ markedly at a lower (i.e. more detailed) level“.

Resende et al. (2013) have elaborated a tool for qualitative analysis of technology transfer offices to clarify the facilitators of technology transfer which would enable technology transfer offices to improve their efficiency and effectiveness (Resende et al. 2013). Weckowska (2015) discusses the different approaches employed by technology transfer offices that shape the commercialization practice of technology transfer offices and their abilities to facilitate technology transfer (Weckowska 2015).

\section{The aims and formation of cooperation projects of Innovation and Business Centre MEKTORY}

\subsection{The concept and aims of Innovation and Business Centre MEKTORY}

The Innovation and Business Centre MEKTORY (abbreviation from „Modern Estonian Knowledge Transfer Organization for You“) of Tallinn University of Technology was opened in 2013. MEKTORY has the following aims (Innovation and Business Centre MEKTORY):

1. To bring together scientists, students and entrepreneurs; solve practical product development problems and generate new intelligent ideas. There are three directions of focus - design and product development, development of business models, and mobile services and media.

2. To tie theoretical studies at the university with the practical side to the maximum possible extent. To prepare better-trained engineers with an experience of cooperation with companies.

3. To encourage students' start-up companies to move forward.

4. To introduce and promote engineering specialities to upcoming generations.

5. To commit to internationalisation to combine different cultures, working habits, ideas and interesting solutions.

The cooperation projects which are under observation in the present paper are one part of broader cooperation with companies of Innovation and Business Centre MEKTORY in many forms. The projects of MEKTORY are initiated based on practical needs. The projects are conducted by interdisciplinary project teams who have at their disposal MEKTORY Centre's infrastructure, including the appliances and test laboratories. Also, projects benefit from the international networks of the university. The cooperation projects of MEKTORY offer companies the opportunity to take part in the working process of a science team and benefit from the contacts with qualified university members and motivated students. 


\subsection{The formation of cooperation projects}

MEKTORY can be viewed as the contact point of the university and companies. The model of an example of a MEKTORY project is depicted in the Figure 1.

The Technology Transfer Office contacts the companies to receive the general topics/fields of research in regard of which the companies may be interested to carry out a cooperation project. Different departments of the company suggest which research questions, topics they would be interested in and which speciality students are required to solve them. Based on the information collected from the companies the Technology Transfer Office contacts the research groups of university dealing with these fields. The research groups of university elaborate the proposals of projects with the estimated costs of the project, which are then sent to companies for review and evaluation. The companies select the projects which they are interested in and may suggest some adjustments to the projects so that the projects would best accord to their needs. The preparation of the proposals of projects may start well before the beginning of the projects. The duration of the projects is approximately 4-8 months. The process of adjustment of the proposal and negotiations with the companies are mediated by the Technology Transfer Office.

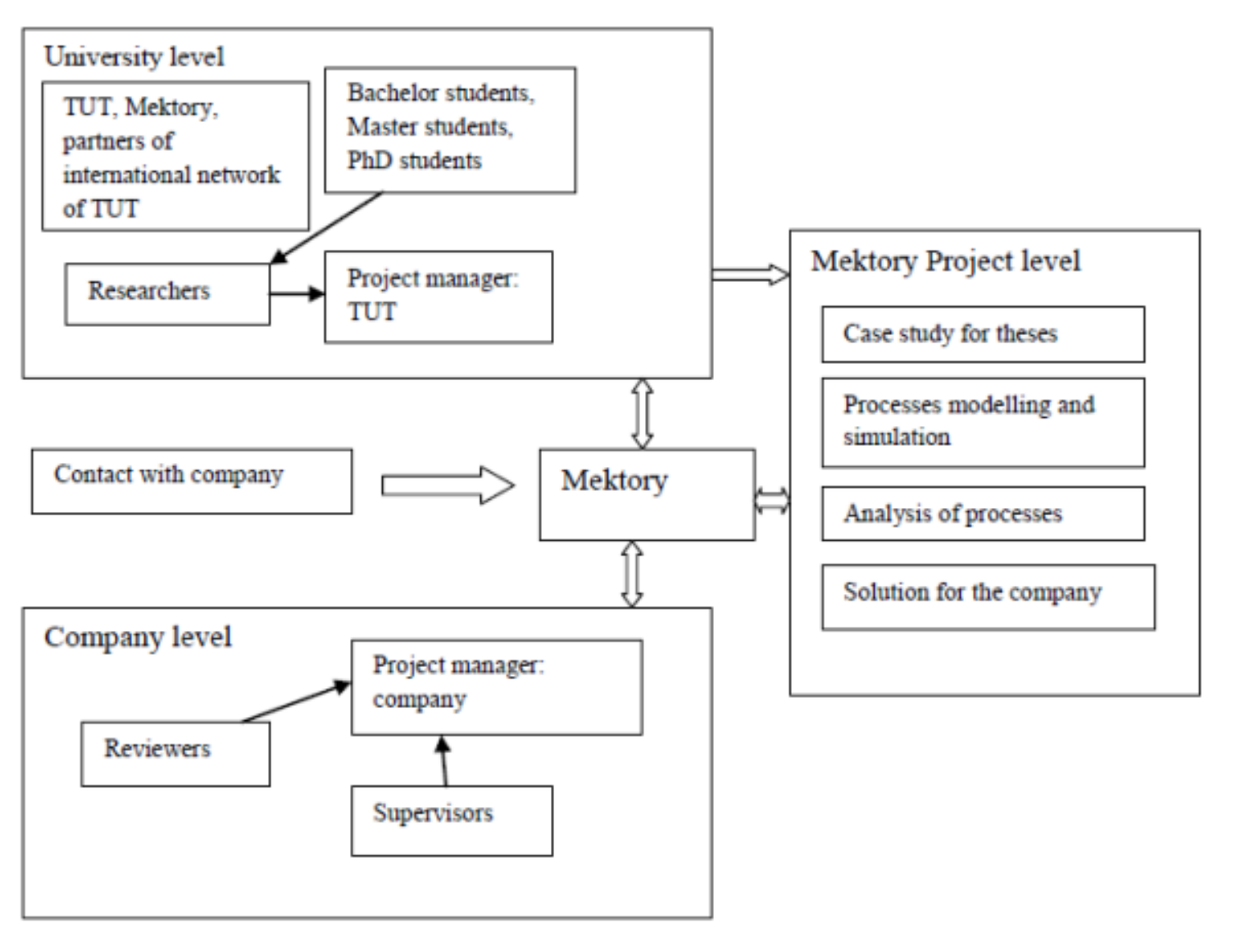

Fig.1. Model of the project

The interdisciplinary project teams consist of the researchers and students. The interdisciplinarity refers to the involvement of researchers and students from different faculties and departments of the university to tackle the various aspects of the problem of the company. The researchers and representatives of the university work on finding the suitable students for the project. In selecting the students, among others the requirements of the company to the students, the qualifications of the student (e.g. the courses the student has taken) and the need for internship of the student are taken into account. The students who are offered the possibility to participate in the project are asked to give their permission to name them as the possible participants of the project in the project proposal sent to the company and are announced after the company has deliberated the project proposal whether the company accepted the project or not. The participation of the students in the project is remunerated. After the project is accepted by the company, the agreements regarding the confidentiality are signed by the 
students and the researchers. The students are expected to participate actively in every phase and part of the project.

The projects have two project managers: project manager from the university and project manager from the company. From the company side, employees of the company who support the project with the relevant company-specific information are involved in the project. Company-side supervisors for the students are appointed, too. Researchers of the project are university-side supervisors for the students. The project also has steering group from the company which reviews the focus, progress and results during the project. If some changes regarding the research questions or scope of the project are needed during the project, the procedure of project change can be initiated. The project team consisting of team of university (i.e. researchers and students) and employees of the company have regular meetings (e.g. once in two weeks) where the current status and questions related to the project are discussed. The project team of university also has its internal meetings every week. The specific tasks and problems to solve in the project are divided among the members of the research group. The projects may include internship and work-shadowing period for students. The practicalities related to the internship for the students are organized by the Human Resources department of the company.

\subsection{The outcomes of cooperation projects}

As the result of the project the final report is prepared. The final report presents the research findings; the analysis of the current situation in the field under observation in the company; the possible improvements suggested by the project; the proposed solutions to the problem. The proposed solutions elaborated in the project can be in different formats. Among others, they can concern processes of the company or a specific part of the process/problem of the company. The final report of the project is compiled by the researchers and students. In addition to the final report the outcomes of the project can be of different type (e.g. application elaborated in the project). The results and the initial version of the final report of the project are presented to the employees of the company involved in the project before the end of the project to receive their feedback. According to the feedback some changes or additions may be done to best accord to the expectations of the company and provide to the company the output of most possible value. Finally, the results and the final report of the project are presented to a larger group of people of the company.

The students have the opportunity to write their theses based on their work in the project. However, writing the thesis is not a prerequisite for participating in the project for the student. The final report of the project can include parts of the final theses of the students but can also be written independently. The theses written on the topic of the project are reviewed by the company and the theses have to follow the requirements concerning the confidentiality. The theses often have two reviews: one from the project-related employee of the company and one from the member of the academic personnel of the university. The company-side reviewer can give evaluation to the thesis e.g. regarding the treatment of the problem-specific details and solution of the problem as well as the practical usage of the recommendations elaborated in the thesis. The university-side reviewer evaluates the accordance of the thesis to academic standards. After the project has ended, feedback from participants is collected and analyzed. The feedback is taken into account when preparing the following projects.

Among others, as benefits of the projects for the companies the analysis of current situation; development of models of future (TO-BE) solutions; received information for further projects have been pointed out. Among others, as benefits of the projects for the university the theses defended (theses were defended under double supervision - one supervisor from university and one supervisor from company); the employment of students; International Applied Collaborative Research experience; input collection for collaborative scientific paper; and received input for further projects have been pointed out. The students have appreciated the workshadowing period, the engagement of the students to the everyday life of the company; the practical topics for writing theses; knowledge and experience gained from the project.

The cooperation contacts arising from the cooperation projects have also contributed to the cooperation of other type. They have provided the opportunity to ask the representatives of the companies to participate in giving the lectures to students at the university where they have introduced their business case from the perspective of the respective course. As important factors contributing to the success of the project priority of 
the project from the stakeholders, the quality of information available and the level of management involvement can be pointed out.

In 2014, 50 projects were conducted with approximately 40 companies (Innovation and Business Centre MEKTORY). The Department of Logistics and Transport had in 20143 projects with 3 different companies where 4 project managers and researchers of the department and 10 students were involved.

\section{Case studies}

\subsection{A transportation company $A$}

The goal of the Project A is optimization of the distribution network of the company in Estonia. The tasks were the following:

1) To create an overview of the existing distribution network, target points and terminal to terminal transportation routes and choice of transportation equipment;

2) To concentrate on bottle necks of the existing network and elaborate new solutions to the problems;

3) To perform cost-benefit analysis of proposed improvements;

The project proposal was discussed with representatives of the transportation company A, head and project manager of the Department of Logistics and Transport of TUT and a project manager of the MEKTORY of TUT. Necessary improvements were introduced into the project proposal. Then the legal officer of Mektory formulated a contract according to rules of the TUT. The representatives of company A overviewed the contract. Then Chief Executive of the Company A and Director of Mektory, who is also Vice Rector of International Affairs of TUT, signed the agreement. The Director of the Department of Logistics and Transport signed the working plan, working schedule of students, list of planned results of the project and also distribution of revenues of the project between the participants. The contract consisted aims of the project, master plan of work, planned results, amount and schedule of financial payments, confidentiality agreement between the company and TUT. Students participating in the project and project manager form the Department of Logistics and Transport of TUT signed individual confidentiality agreements with the company A. Afterwards, the biweekly meetings were organised where project managers from the Department of Logistics and Transport and Mektory and representatives of the company A with the team of students participated. The results of the project for the last period, issues related to following the scope of the project and necessary improvements of work were discussed during the meetings.

The working team of four students of TUT Logistics Department made observations in terminals, interviews with drivers and documented a working day of four drivers during a week. The results were documented and discussed with the head of department of the transportation company A. The observation part and interviews with drivers already gave some information on necessity of more detailed guidelines for drivers in planning their daily activities.

The team fulfilled the tasks of the project, though they spent two months more than was initially planned. The company A accepted that delay because partly the reason was lack of some data for cost -benefit analysis. The project proposed some new routes and the quite substantial changes in transport equipment. The company postponed these changes but applied the optimization model in one region to validate the theoretical approach. 


\subsection{An electronics company $B$}

The goal of the Project B was use of statistical methods to clarify inter-relationships between different symptoms of failure of components of the equipment produced by the electronics company $\mathrm{B}$. The project treatment followed the same procedure as project A.

The key question was which symptoms (problems) are likely to cause the product to fail the retest without repair. In case of these symptoms, it may be useful to omit the retest and send the product directly to repair. This may contribute to the reduction of the testing time.

The aim was to clarify which symptoms have statistically significantly higher frequency of occurrence in the group where both the first test as well as the retest showed the problem. This question was clarified by means of chi-square test (Curtis, Youngquist, 2013, 179-180). Based on the analysis, the list of symptoms was elaborated in case of which the recommendation is to omit the retest. The benefits of applying the recommendation of not carrying out retests for particular symptoms include possibility to solve the symptom more quickly and it enables to test other products earlier.

The team reported the results to the managers and specialists of the respective department of the company B. The company accepted the report. The lively discussion followed and members of the team of TUT explained the applied methods and results in a very detail way.

\section{Concluding remarks}

In the knowledge-based society, the importance of knowledge transfer and cooperation projects between academic and business sector increases. Therefore the importance of the analysis of the process and clarification of the objectives of the cooperation projects has to be underlined. Both the qualitative as well as quantitative studies contribute to this analysis. To further promote and facilitate the cooperation projects within the frame of an intermediating organization between academic and business sector - technology transfer office, the contribution of the continuous monitoring and analysis of the objectives and feedback received from the projects could be used. As important factors contributing to the success of the project priority of the project from the stakeholders, the quality of information available and the level of management involvement can be pointed out. In the paper, the formation of the university-business cooperation projects was described on the example of the Innovation and Business Centre MEKTORY of Tallinn University of Technology. The cooperation projects which were under scrutiny in the present paper constitute one part of the broader cooperation of MEKTORY with companies. In case of the cooperation projects active participation of both the actors of the university as well as the company in every phase of the project can be pointed out.

\section{References}

Ankrah, S. N.; Burgess, T. F.; Grimshaw, P.; Shaw N. E. 2013. Asking both university and industry actors about their engagement in knowledge transfer: What single-group studies of motives omit, Technovation 33(2-3): 50-65. doi:10.1016/j.technovation.2012.11.001

Bekkers, R.; Freitas, I. M. B. 2008. Analysing knowledge transfer channels between universities and industry: To what degree do sectors also matter?, Research Policy 37(10): 1837-1853. doi:10.1016/j.respol.2008.07.007

Berbegal-Mirabent, J.; García, J. L. S.; Ribeiro-Soriano, D. E. 2015. University-industry partnerships for the provision of R\&D services, Journal of Business Research 68(7): 1407-1413. doi:10.1016/j.jbusres.2015.01.023

Curtis, K.; Youngquist, S.T. 2013. Part 21: Categoric Analysis. Pearson Chi-Square Test, Air Medical Journal, 32(4): 179-180.

Eesti teadus- ja arendustegevuse ning innovatsiooni strateegia 2014-2020 „Teadmistepõhine Eesti“. https://www.hm.ee/sites/default/files/59705_teadmistepohine_eesti_est.pdf

Etzkowitz, H.; Leydesdorff, L. 2000. The dynamics of innovation: from National Systems and „Mode 2“ to a Triple Helix of universityindustry-government relations, Research Policy 29(2): 109-123. doi:10.1016/S0048-7333(99)00055-4 
Gibbons, M.; Limoges, C.; Nowotny, H.; Schwartzman, S.; Scott, P.; Trow, M. 1994. The New Production of Knowledge: The Dynamics of Science and Research in Contemporary Societies. London: Published by Sage.

Hsu, D. W. L.; Shen, Y.-C.; Yuan, B. J. C.; Chou, C. J. 2015. Toward successful commercialization of university technology: Performance drivers of university technology transfer in Taiwan, Technological Forecasting \& Social Change 92: 25-39. doi:10.1016/j.techfore.2014.11.002

Innovation and Business Centre MEKTORY. http://www.ttu.ee/et/?id=23694 (01.04.2015)

O'Kane, C.; Mangematin, V.; Geoghegan, W.; Fitzgerald, C. 2015. University technology transfer offices: The search for identity to build legitimacy, Research Policy 44(2): 421-437. doi:10.1016/j.respol.2014.08.003

Resende, D. N.; Gibson, D.; Jarrett, J. 2013. BTP - Best Transfer Practices. A tool for qualitative analysis of tech-transfer offices: A cross cultural analysis, Technovation 33(1): 2-12. doi:10.1016/j.technovation.2012.09.001

Santoro, M. D.; Chakrabarti, A. K. 2002. Firm size and technology centrality in industry-university interactions, Research Policy 31(7): 1163-1180.

Santoro, M. D.; Gopalakrishnan, S. 2000. The institutionalization of knowledge transfer activities within industry-university collaborative ventures, Journal of Engineering and Technology Management 17(3-4): 299-319. doi:10.1016/S0923-4748(00)00027-8

Schartinger, D.; Rammer, C.; Fischer, M. M.; Fröhlich, J. 2002. Knowledge interactions between universities and industry in Austria: sectoral patterns and determinants, Research Policy 31(3): 303-328. doi:10.1016/S0048-7333(01)00111-1

Tvaronavičienè, M.; Černevičiūtè, J. 2015. Technology transfer phenomenon and its impact on sustainable development, Journal of Security and Sustainability Issues 5(1): 87-97. DOI: http://dx.doi.org/10.9770/jssi.2015.5.1(7)

Weckowska, D. M. 2015. Learning in university technology transfer offices: transactions-focused and relations-focused approaches to commercialization of academic research, Technovation 41-42: 62-74. doi:10.1016/j.technovation.2014.11.003

Eva BRANTEN graduated from Tallinn School of Economics and Business Administration of Tallinn University of Technology in 2015 (MA in Social Sciences). She is Project Research Associate with the Department of Logistics and Transport of Tallinn University of Technology.

Alari PURJU is Head of Department of Logistics and Transport of Tallinn University of Technology (TUT) and a Visiting Professor. He has been the Dean of the Faculty of Economics and Business Administration of TUT and an Advisor to the Minister of Economic Affairs of Estonia as well as a Consultant to the World Bank (The Commission for Growth and Development), the OECD and the EU Commission.

This is an open access journal and all published articles are licensed under a Creative Commons Attribution 4.0 International License 